\author{
ks. Michał Drożḋ \\ Uniwersytet Papieski Jana Pawła II w Krakowie
}

\title{
DEMOKRACJA - MIĘDZY PROPAGANDĄ \\ A PUBLIC RELATIONS \\ RECENZJA KSIĄŻKI
}

Mirosław Lakomy, Doktryna Bernaysa. Demokracja - między propaganda a public relations, Wydawnictwo Naukowe Akademii Ignatianum, Kraków 2019, 316 stron, ISBN 978-83-7614-436-8.

Monografia autorstwa Mirosława Lakomego, Doktryna Bernaysa. Demokracja - między propaganda a public relations, jest ważnym, na gruncie polskim, przedsięwzięciem naukowym i wydawniczym, podejmującym aktualną tematykę manipulacji masami w komunikowaniu politycznym. Celem pracy jest - jak pisze Lakomy - , analiza dorobku praktycznego i teoretycznego Edwarda Bernaysa na tle dokonań psychologów społecznych epoki oraz jego ocena z punktu widzenia założeń demokracji” (s. 5). Autor pracy uzasadnia w swojej monografii hipotezę pracy, że Edward Bernays wypracował doktrynę niejawnego i nieetycznego sprawowania władzy przez elity biznesowe i polityczne w ustrojach demokratycznych, opierając się na technologii fabrykowania przyzwolenia (engineering of consent) oraz kreowania informacji (creating news). Autor podejmuje w swojej publikacji ważny współcześnie temat politologiczny: wykorzystania manipulacyjnych mechanizmów skutecznej perswazji na masy, celem uzyskania pożądanych postaw, zachowań i decyzji wyborczych. Sam tytuł sugeruje działania perswazyjne w demokracji, które nabierają cech manipulacyjnego oddziaływania na ludzi w systemach demokracji. W sytuacji współczesnej hybrydowej wojny informacyjnej przywołanie przez Autora starej koncepcji Edwarda Bernaysa jest jak najbardziej aktualne, gdyż pokazuje ponadczasowe próby oddziaływania perswazyjnego na ludzi, wykorzystującego nieetyczne narzędzia sterowania ludzkim myśleniem i działaniem. Gratulacje należą się zarówno Wydawnictwu, jak i Autorowi za solidną empiryczną pracę badawczą, analizę źródłową i prezentację całego kontekstu teoretycznego koncepcji Edwarda Bernaysa w dobie cywilizacji medialno-informacyjnej. 
Publikacja ma charakter komunikologiczno-politologiczny, ukazując mechanizmy propagandy i skrajnie rozumianej public relations jako narzędzia skutecznej indoktrynacji mas, celem łatwego manipulowania ich działaniami i wyborami. Doktryna Bernaysa zasadza się bowiem na założeniu istnienia podziału społecznego na ,inteligentne i uprzywilejowane elity oraz łatwo poddające się manipulacji „masy”, a tym samym funkcjonowaniu w ustrojach demokratycznych stratarchii, dzięki czemu praca wpisuje się w paradygmat elityzmu" (s. 6).

Publikacja jest nowatorska, ponieważ nie tylko pokazuje całokształt dorobku politologicznego Edwarda Bernaysa, ale dostarcza solidnej empirycznej wiedzy na temat faktycznego wykorzystywania narzędzi propagandowo-perswazyjnych w społeczeństwach demokratycznych, rządzonych przez elitę technokratyczną, która manipuluje ludźmi według starych reguł psychologii zbiorowości. Praca zawiera pięć rozdziałów, które w sposób postępujący metodologicznie i merytorycznie, ukazują rozwój narzędzi oddziaływania na ludzi i praktykę ich stosowania od I wojny światowej po czasy współczesne. Praca ma interesującą metodologicznie kompozycję. Autor ukazuje najpierw jakość propagandy w okresie I wojny światowej, następnie ukazuje historię rozwoju dwóch koncepcji public relations na przykładzie dorobku Ivy’ego Lee oraz Edwarda Bernaysa. Trzeci i czwarty rozdział zawiera analizę wybranych dokonań Edwarda Bernaysa o charakterze biznesowym, politycznym i naukowym. Ostatni rozdział monografii jest próbą analizy efektywności oddziaływania perswazyjnego na masy przez elity rządzące w kontekście odpowiedzi na dylemat, czy w społeczeństwach demokratycznych mamy do czynienia z władzą demosu czy władzą nad demosem? Ten ostatni rozdział i zawarty w jego tytule dylemat jest kwintesencją pracy, ukazującą manipulacyjny charakter współczesnego komunikowania politycznego. Autor podejmuje się próby odpowiedzi na pytania o jakość demokracji w sytuacji permanentnego oddziaływania na ludzi narzędziami perswazji i propagandy naruszającymi ich świadomość i wolność. Próby diagnozowania szans, wyzwań i zagrożeń dla demokracji ze strony polityczno-technokratycznych manipulatorów nie mają jeszcze charakteru szczegółowych analiz, ale odkrywają trendy, tendencje negatywnego rozwoju demokracji w społeczeństwie medialno-informacyjnym.

Recenzowana pozycja jest monografią analityczno-źródłową, opracowaną według przemyślanej metodologii analizy poszczególnych obszarów tematycznych związanych z głównym problemem pracy: wykorzystaniem narzędzi propagandowo-perswazyjnych w manipulowaniu społeczeństwem demokratycznym. Ważną i mocną metodologicznie stroną pracy jest jej dokumentacja źródłowa. Autor opiera swoje analizy i wyciągane z nich wnioski na własnych badaniach empirycznych, jak i sięga do konkretnej i bogatej literatury przedmiotu. Monografia jest przygotowana bardzo solidnie, $\mathrm{z}$ dużym wysiłkiem kwerendalnym, redakcyjnym i badawczym. Wartym docenienia jest część bibliograficzna publikacji. Bogata bibliografia, również internetowa, treści źródłowych, czyni z publikacji znakomite narzędzie do dalszych prac badawczych.

Monografia jest potrzebna w dzisiejszym świecie badawczym - nie tylko znawcom współczesnego komunikowania politycznego, studentom politologii, socjologii i dziennikarstwa i komunikacji społecznej oraz innych kierunków, badaczom Internetu i nowych technologii itp., ale także politykom, którzy często zawężają znajomość 
problemów dzisiejszej cywilizacji informacyjnej tylko do problematyki bieżących sporów politycznych. Nie widzą przy tym szerokiego i ważnego dla polityki komunikowania opartego na etyczności oddziaływania na opinię publiczną, zdolnego - jak pokazują to sytuacje polityczne $\mathrm{w}$ dzisiejszym świecie - zmieniać bieg i procesy polityczne oraz systemy władzy. Publikacja jest także cenną pomocą dla teoretyków i wykładowców, zwłaszcza tych, którzy podejmują się zadań formowania społeczeństwa obywatelskiego. 